\title{
WISATA EDUKASI BERBASIS ENERGI TERBARUKAN SEL SURYA
}

\section{EDUCATION TOURISM BASED ON RENEWABLE ENERGY SOLAR CELLS}

\author{
${ }^{1)}$ Dian Nova Kusuma Hardani, ${ }^{2)}$ Itmi Hidayat Kurniawan, ${ }^{3)}$ Winarso \\ ${ }^{1,2,3)}$ Program Studi Teknik Elektro, Fakultas Teknik dan Sains \\ Universitas Muhammadiyah Purwokerto \\ Jl. Raya Dukuhwaluh PO BOX 202, Purwokerto \\ Email: diannova.kh@ump.ac.id
}

\begin{abstract}
ABSTRAK
Kegiatan ini bertujuan untuk memberdayakan masyarakat untuk mewujudkan kemandirian dan kesejahteraan melalui optimalisasi potensi masyarakat berupa sumber daya yang ada. Kegiatan ini juga membantu meningkatkan konsidi social ekonomi warga, serta mempermudah akses terhadap informasi dan ilmu pengetahuan. Kelompok sasaran dari kegiatan ini adalah Desa Wisata Pagak yang dikelola oleh BUMDes dan Pokdarwis Desa Pagak. Metode yang digunakan dalam menyelesaian pemasalahan mitra antara lain melalui pendidikan masyarakat, difusi ipteks, pelatihan, dan advokasi. Hasil kegiatan ini adalah adanya sistem pembangkit tenaga listrik surya sebagai bentuk pemanfaatan potensi energy matahari untuk wisata edukasi sekaligus dapat digunakan untuk penerangan di area Desa Kitiran Rawa Lutung.
\end{abstract}

Kata kunci: Wisata; Edukasi; Energi; Surya

\section{ABSTRACT}

This activity aims to empower the community to realize independence and prosperity through optimizing the potential of the population in the form of existing resources. This activity also helps improve the socio-economic conditions of citizens, as well as facilitate access to information and knowledge. The target groups of this activity are the Pagak Tourism Village which is managed by BUMDes and Pokdarwis of Pagak Village. The methods used in resolving partner problems include, among others, community education, science, and technology diffusion, training, and advocacy. The result of this activity is the existence of a solar power generation system as a form of harnessing the potential of solar energy for educational tourism as well as being able to be used for lighting in the area of Kitiran Rawa Lutung Village.

Keywords: Tourism; Education; Energy; Solar

\section{PENDAHULUAN}

Desa Pagak merupakan desa yang berada di Kecamatan Purwareja Klampok, Klampok sebagai rintisan kota pusaka di wilayah barat Kabupaten Banjarnegara merupakan pintu pariwisata dan peluang besar di wilayah barat yang menghubungkan 4 penjuru besar (Purbalingga, Banyumas, Kebumen, Banjarnegara). Pada pertengahan bulan
Agustus 2017, Pemerintah Desa Pagak merintis kota pusaka di Kecamatan Purwareja Klampok dengan membuat pergerakan Desa Wisata Pagak yang berbasis masyarakat dalam Bidang Pertanian dan Wisata Perkampungan. Terwujudnya Desa Wisata ini diharapkan dapat menaikan Pendapatan Asli Desa (PAD). Selain itu, dengan adanya kawasan wisata di Kecamatan Purwareja 
Klampok membuat langkah Pemerintah Desa Pagak dalam membangun Desa Wisata semakin optimis dan didukung infrastruktur jalan yang telah memadai. Potensi lain yang bisa dijadikan acuan untuk menjadikan Desa Pagak sebagai Desa Wisata adalah lokasi yang berdekatan dengan BLKP Purwareja Klampok, kerajinan kramik Klampok, letak geografis Desa Pagak yang berada di tengah-tengah/ pusat desa sekitar dan sangat strategis sebagai titik kumpul keramaian dari desa disekitarnya, serta potensi lainya yang dapat di kemas sebagai kawasan wisata di wilayah Purwareja Klampok.

Pihak yang terlibat dalam pengembangan proyek adalah seluruh masyarakat Desa Pagak. Adapun pengelolaannya Desa Wisata ini ditangani oleh Badan Usaha Milik Desa (BUMDes) ASTAGINA dan Kelompok Sadar Wisata (Pokdarwis) Krida Wisata. BUMDes bertugas untuk meningkatkan kesejahteraan asli desa. Sebenarnya, tidak ada patokan bagaimana cara agar desa bisa lebih sejahtera, tetapi semua kembali pada apa yang dimiliki desa dan bagaimana mengembangkan potensi tersebut. Oleh karena itu, BUMDes harus dapat mengembangkan Desa Wisata ini untuk membangun ekonomi dan SDM secara beriringan dan terintegrasi. Peran sertanya dalam pembangunan desa sangat besar. Desa Pagak ini memiliki banyak hamparan lahan pertanian yang siap untuk dimanfaatkan sebagai destinasi wisata melalui BUMDes. Keberadaan Badan Usaha Milik Desa (BUMDes) sejatinya tidak bisa dilepaskan dari peranan desa dalam memajukan kehidupan ekonomi di wilayahnya. BUMDes mutlak harus ada sebagai salah satu sarana peningkatan pendapatan asli desa. Lebih jauh dari itu, semangat membangun BUMDes adalah semangat membangun perekonomian rakyat dari sub pemerintahan terkecil yaitu Desa (Kusmuriyanto, Feriady, \& Susilowati, 2019). BUMDes mengelola usaha yang berada di desa dan melaporkan hasil pengelolaan tersebut kepada stakeholder terkait dengan tujuan untuk kemakmuran masyarakat desa. Diantara informasi yang dihasilkan oleh BUMDes dalam melaporkan kondisi keuangan beserta kinerja yang telah dihasilkan dalam suatu periode tertentu adalah Laporan Keuangan (Andi, Marlina, \& Fahmi, 2016).

Kelompok Sadar Wisata adalah merupakan salah satu alternative pengembangan pariwisata terkait dengan kampanye sadar wisata. Pengembangan pariwisata nusantara yang dilakukan Kelompok Sadar Wisata (Pokdarwis) melalui berbagai kegiatan antara lain pembinaan masyarakat melalui kelompok swadaya dan swakarsa masyarakat yang berfungsi sebagai penggerak pembangunan pariwisata (Setianingsih, Amdani, \& Utrisno, 2017). Pokdarwis merupakan kelompok yang bergerak secara swadaya. Ini artinya pengembangan kepariwisataan yang dilakukan di desa bersumber dari kekuatan desa sendiri dengan segala potensinya. Pokdarwis juga harus membangun dirinya secara swakarsa alias menciptakan pengembangan berdasar potensi kreativitas yang mereka miliki karena merekalah yang memiliki kuasa atas pengembangan desa dengan segala sumber daya yang mereka miliki.

Hasil wawancara dengan dua kelompok mitra dan hasil survey di lapangan terdapat beberapa permasalahan yaitu: (a) Sumber keuangan untuk mengembangkan desa wisata yang masih terbatas, (b) Kesadaran masyarakat akan pentingnya desa wisata masih kurang,(c) Belum dapat memanfaatkan potensi alam yang ada dan mengkolaborasikannya dengan teknologi sehingga bisa dijadikan sebagai wisata edukasi, (d) Cara menarik wisatawan untuk berkunjung ke tempat tersebut belum maksimal untuk meningkatkan pendapatan desa, (e) Perlu pendampingan dari tenaga akademik untuk transfer knowledge. 
Berdasarkan permasalahan tersebut maka Program Pengembangan Desa Mitra (PPDM) bertujuan untuk membantu menyelesaikan masalah yang dihadapi oleh mitra, mampu menuntun masyarakat desa ke arah kehidupan yang lebih sejahtera, mewujudkan masyarakat yang dinamis, memberdayakan masyarakat dalam mewujudkan kemandirian dan kesejahteraan berbasis pada optimalisasi potensi masyarakat agar mampu mendayagunakan dan mengoptimalkan potensi sumber daya yang ada, membantu meningkatkan kondisi sosial ekonomi warga, serta mempermudah akses warga terhadap informasi dan ilmu pengetahuan.

\section{METODE}

Kelompok sasaran dalam PPDM ini adalah Badan Usaha Milik Desa (BUMDes) Astagina dan Kelompok Sadar Wisata (Pokdarwis) Krida Wisata yang merupakan pengelola Desa Wisata Pagak. BUMDes bertugas untuk meningkatkan kesejahteraan asli desa. Sedangkan Pokdarwis bertugas mengembangkan kepariwisataan yang di desa yang bersumber dari kekuatan desa sendiri dengan segala potensinya.

Ada beberapa metode yang digunakan dalam merealisasikan kegiatan PPDM ini, yaitu:

\section{Pendidikan Masyarakat}

Metode yang dilakukan dengan melaksanakan penyuluhan guna meningkatkan kesadaran masyarakat akan pentingnya Desa Wisata dalam proses pembangunan desa agar perekonomian menjadi lebih maju.

\section{Difusi Ipteks}

Produk yang dihasilkan berupa sistem tenaga listrik berbasis tenaga surya. Ini merupakan objek yang dapat digunakan untuk transfer pengetahuan kepada para pengunjung.

\section{Pelatihan}

Pengelola diberikan pelatihan dalam memeliharasistem pembangkit listrik tenaga surya. Tujuan kegiatan ini adalah jika terjadi permasalahan kerusakan atau trouble pengelola dapat memperbaikinya.

\section{Advokasi}

Kegiatan yang dilakukan berupa pendampingan selama kurun waktu tertentu. Bagian pendampingan pengelolaan Desa Wisata Pagak, pihak pengelola yang terkait diajarkan hal-hal yang sangat diperlukan dalam memelihara pembangkit listrik tenaga surya agar tetap berlanjut kemanfaatannya, antara lain: cara mengoperasikan sistem, cara mengatasi permasalahan jika sewaktuwaktu aliran listrik terganggu, dan cara merawat panel surya.

Keseluruhan metode yang dilaksanakan ini menitikberatkan pada pendekatan partisipatif dalam pengembangan masyarakat atau disebut dengan metode PRA (Participatory Rural Appraisal). PRA ialah suatu pendekatan dan metode untuk mempelajari kondisi dan kehidupan pedesaan dari, dengan, dan oleh masyarakat desa. Sejumlah langkah dan kegiatan dalam suatu siklus PRA adalah pengenalan awal masalah/kebutuhan; perumusan masalah dan penetapan prioritas; identifkasi alternative pemecahan dan pengembangan gagasan; pemilihan alternatif pemecahan masalah yang paling tepat; perencanaan guna menerapkan gagasan pemecahan masalah yang terpilih; pelaksanaan/pengorganisasian;

pemantauan dan pengarahan kegiatan; refleksi berupa evaluasi dan rencana tindak lanjut (Chambers, 1994).

Adapun tahapan yang dilakukan dimulai dengan tahap persiapan. Pada tahap ini, kegiatan yang dilakukan berupa survey kondisi desa mitra terkait pembuatan Wisata Edukasi Berbasis Energi Terbarukan Sel Surya di Desa Pagak Banjarnegara, koordinasi dengan 
Perangkat Desa Mitra untuk optimalisasi Sumber Daya Desa yang bisa digunakan serta sosialisasi mengenai edukasi energi terbarukan menggunakan sel surya serta penerapannya di lingkungan Desa.

Berdasarkan hasil penelitian sebelumnya, pemasangan sel surya ini efektif karenawilayah Indonesia berada di daerah tropis. Penggunaan sel surya di Pondok Pesantren Nurul Imansangat membantu karena kebutuhan energi listrik di Pondok Pesantren Nurul Iman sangat besar. Halini dapat dihitung dari biaya yang dikeluarkan per bulan oleh Pondok Pesantren Nurul Iman. Dengan audit energi dapat dikurangi beban yang digunakan sebesar $1.250 \mathrm{~W}$. Lebih dari sepertiga yang dapat dikurangi biaya listriknya dengan sel surya(Abrori, Sugiyanto, \& Niyartama, 2017).

Tahap berikutnya adalah tahap pembuatan dan installasi pembangkit listrik surya. Secara umum produk alat yang berbentuk prototipe sistem pembangkit listrik tenaga surya ini dapat dijadikan ikon yang menarik perhatian pengunjung sekaligus sebagai sarana pembelajaran. Papan informasi petunjuk pemakaian dan sekilas proses konversi energi matahari menjadi energi listrik diberikan untuk menambah wawasan pengunjung. Adapun skema system pembangkit listrik tenaga surya ditunjukkan pada Gambar 1.

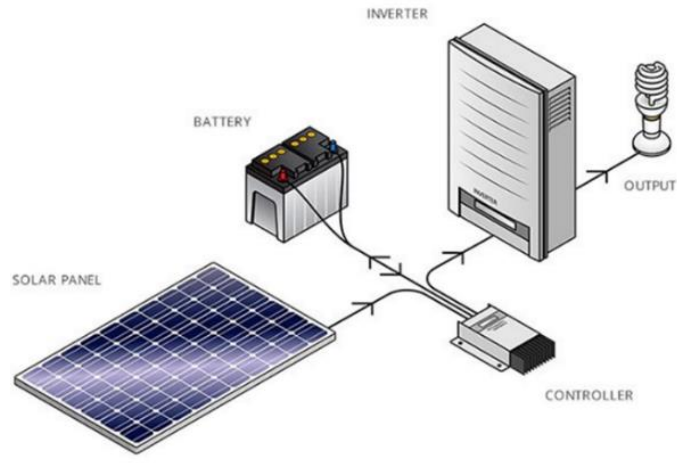

Gambar 1. Skema sistem pembangkit listrik tenaga surya

Umumnya, panel surya dipasang secara tetap (fixed) pada dudukannya.
Untuk negara-negara 4 musim teknik yang diadopsi umumnya adalah dengan menghadapkan panel tersebut kearah selatan (bagi negara-negara di belahan bumi utara) atau ke arah utara (bagi negara-negara di belahan bumi selatan). Keadaan sedikit berbeda untuk negaranegara tropis (letak geografisnya berada dekat garis khatulistiwa). Untuk negaranegara ini, cara pemasangan yang dilakukan cenderung lebih datar. Tahap akhir dari program ini adalah tahap pelatihan dan pendampingan bagi pengelola. Bagian pendampingan pengelolaan Desa Wisata Pagak, pihak pengelola yang terkait diajarkan hal-hal yang sangat diperlukan dalam memelihara pembangkit listrik tenaga surya agar tetap berlanjut kemanfaatannya, antara lain: pelatihan cara mengoperasikan sistem, cara mengatasi permasalahan jika sewaktu-waktu aliran listrik terganggu, serta cara merawat panel surya dan komponen lainnya agar awet.

\section{HASIL DAN PEMBAHASAN}

Pelaksanaan pengabdian bagi masyarakat dengan program pengembangan desa mitra sudah berjalan $100 \%$ dari seluruh rangkaian program ini. Apa yang menjadi harapan dari desa mitra sudah terpenuhi yakni pemanfaatan potensi tenaga surya untuk penerangan dan juga sebagai sarana edukasi di lokasi wisata yang sedang dibangun. Program ini dapat mewujudkan terjadi peningkatan pemberdayaan masyarakat dalam mewujudkan kemandirian dan kesejahteraan berbasis pada optimalisasi potensi masyarakat agar mampu mendayagunakan dan mengoptimalkan potensi sumber daya yang ada, membantu meningkatkan kondisi sosial ekonomi warga, dan mempermudah akses warga terhadap informasi dan ilmu pengetahuan.

Dari segi ilmu pengetahuan, pembangkit listrik tenaga surya merupakan salah satu pemanfaatan energi terbarukan yang berfungsi untuk mengubah energi surya berupa panas 
matahari menjadi energi listrik untuk kebutuhan sehari - hari. Panel surya juga sering disebut dengan sel photovoltaic.Dimana, sel surya atau panel surya ini bergantung ada efek photovoltaic untuk menyerap energi panas matahari dan mengonveksiknya menjadi energi listrik.

Kampung Kitiran Rawa Lutung yang yang nantinya dijadikan sebagai obyek wisata ini memiliki area yang cukup luas. Namun kendalanya belum ada penerangan sama sekali di daerah tersebut. Setelah didiskusikan dengan Kepada Desa Pagak, Bapak Sudarwo, akhirnya memutuskan untuk memasang 6 titik lampu yang dipasang secara terpisah di 4 Gazebo masing-masing 1 lampu, di menara 2 lampu dipasang di luar dan dalam. Panel surya ditempatkan di atas menara supaya mendapat energi secara maksimal. Sedangkan box panel, box accu dan papan informasi diletakkan di dalam menara.

Proses perakitan box panel inverter dan controllertelah berhasil dilaksanakan. Inverter merupakan suatu perangkat elektronika yang dapat mengubah arus listrik searah (DC) ke arus listrik bolakbalik (AC) pada tegangan dan frekuensi yang dibutuhkan sesuai dengan perancangan rangkaiannya. Karena arus yang diperoleh dari panel surya berupa arus DC maka untuk mengubahnya ke arus AC supaya dapat digunakan untuk penerangan skala besar harus menggunakan inverter. Jenis inverter yang digunakan pada kegiatan ini adalah inverter TOP UP 12V-1000W. Spesifikasi alat adalah tegangan masukan DC $12 \mathrm{~V}$, tegangan keluaran AC 220-230V, dan maksimal daya keluaran 1000W. Controller disini maksudnya adalah Solar Charge Controller yang berfungsi untuk mengatur arus pada saat pengisian ke baterai agar tidak terjadi over charging dan over voltage. Jenis yang digunakan adalah Solar Charge Controller PWM 30A. Sistem ini mampu menyesuaikan otomatis dan dapat bekerja maksimum baik saat matahari terik atau mendung.

Panel surya tidak bisa diletakkan begitu saja di sembarang tempat sehingga dibutuhkan rangka agar dapat diatur dengan mudah posisinya. Posisi sudut penempatan panel surya sangat mempengaruhi maksimal tidaknya penyerapan energi yang dilakukan. Penyimpanan energi dilakukan oleh baterai dalam hal ini aki jenis basah. Agar aki tersebut aman dan tetap terjaga kondisinya maka dibutuhkan box untuk menyimpannya.

Proses selanjutnya adalah pemasangan panel surya, box panel dan instalasi listrik. Pekerjaan pertama yang dilakukan pada tahap ini adalah pemasangan box panel dan box aki di dalam menara. Selanjutnya penarikan kabel dari box panel ke masing-masing Gazeboguna penerangan di empat Gazebo yang dibantu oleh warga. Setelah kabel berhasil dihubungkan selanjutnya pemasangan saklar dan fitting lampu sekaligus dikoneksikan ke jalur induk box panel. Tahap instalasi berikutnya dilakukan adalah pemasangan rangka panel surya dan panel suryanya yang berada di atas menara.

Sel surya jenis monokristal (monocrystalline)merupakan panel yang paling efisien, menghasilkan dayalistrik persatuan luas yang paling tinggi. Memiliki efisiensisampai dengan $15 \%$. Kelemahan dari panel jenis iniadalah tidak akan berfungsi baik ditempat yang cahayamataharinya kurang (teduh), efisiensinya akan turundrastis dalam cuaca berawan.Photovoltaic cell selalu dilapisi oleh penutup yangberasal dari gelas. Seperti barang dari gelas lainnya, makaoptical input dari photovoltaic cell juga sangat dipengaruhioleh orientasinya terhadap matahari karena variasi sudutdari pantulan gelas.Berdasarkan hasil percobaan, didapatkan trendlinehubungan antara sudut datang sinar matahari dengantegangan yang dihasilkan. Dari analisis data didapat fungsiy $=-0.0001 \times 2$ 
$+0.0071 \mathrm{x}+19.714$ dengan $\mathrm{R} 2=$ 0.9672.Energi yang dihasilkan jika menggunakan solar trackerdengan sudut deviasi $5^{\circ}$ menghasilkan energi yang palingbesar(Rif'an et al., 2012).Berdasarkanhasil analisis desain sistem pembangkitlistrik tenaga surya dengan panel surya $50 \mathrm{WP}$, posisi sudut kemiringan modul suryasaat mengikuti arah pergerakan matahari menghasilkantegangan rata-rata rangkaian terbuka (Voc) $18,27 \mathrm{~V}$ danarus rata-rata hubungan singkat (Ioc) 2,49A dan posisitegak lurus (horizontal) menghasilkan tegangan rata-ratarangkaian terbuka (Voc) 19,67V. Sementara itu arus rata-rata hubungan singkat (Ioc) 1,40A. Posisi sudutkemiringan modul surya saat mengikuti arah pergerakanmatahari menghasilkan Daya Keluaran (Pout) sebesar38,24 W dan posisi tegak lurus (horizontal)menghasilkan Daya Keluaran (Pout) 21,91 W(Ramadhan, Diniardi, \& Mukti, 2016).Dengan pertimbangan tersebut, maka pemasangan panel surya di Kampung Kitiran Rawalutung seperti ditunjukkan pada Gambar 2.

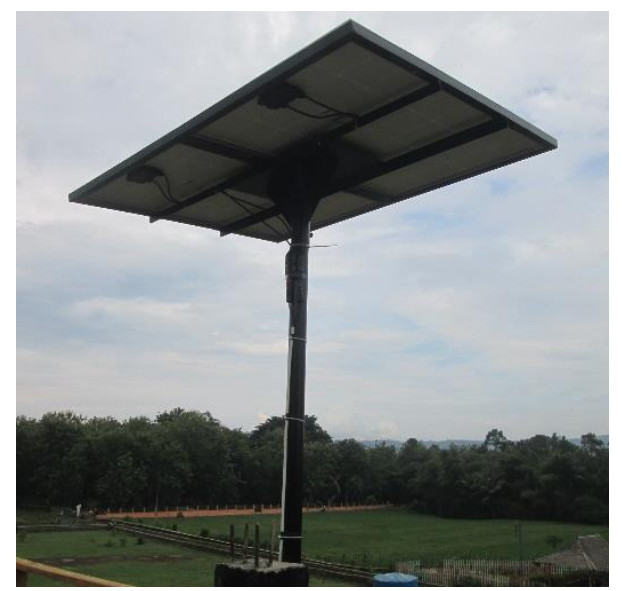

Gambar 2. Posisi pemasangan panel surya

Perkerjaan berikutnya dilakukan adalah pemasangan kabel panel surya menuju ke box panel yang berada di dalam menara. Setelah terkoneksi semuanya, dilakukan uji coba rangkaian solar cell berbeban lampu LED untuk penerangan Gazebo. Terakhir, pemasangan papan informasi di dalam menara. Adapun informasi yang diberikan untuk pengunjung seperti ditunjukkan pada Gambar 3. Penentuan lokasi di dalam menara dengan pertimbangan keamanan dan terhindar dari panas secara langsung maupun hujan. Seluruh pekerjaan yang dilaksanakan telah dibantu oleh Kepala Desa dan warga.

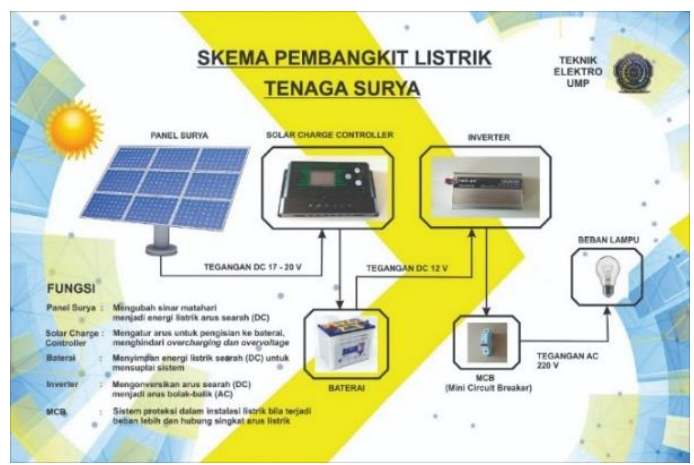

Gambar 3. Papan Informasi Kerja Sistem Pembangkit

Pada Desa Wisata Pagak, Kampuung Kitiran Rawalutung, jumlah panel surya yang dipasang sebanyak dua dengan spesifikasi GH-100WP Mono sehingga jika terpasang dua buah panel menjadi 200 WP. Maksimal daya yang dapat digunakan sebesar 40W untuk pemakaian selama 5 jam atau $20 \mathrm{~W}$ untuk pemakaian 10 jam. Daya yang tersimpan tidak dapat maksimal, hal ini karena pengaruh perubahan intensitas matahari terhadap daya keluaran panel surya (Yuliananda, Sarya, \& Hastijanti, 2015).Arus yang diproduksi paling tinggi terjadi sekitar jam 12.30, dengan nilai arus sebesar 13A dan tegangan 14 Volt DC. Energi yang dihasilkan pada siang hari digunakan untuk mensuplaibeban lampu mulai dari pukul 17.00 - 06.00 dengan rerata setiap malam energi yang dapat digunakan sebesar1,027 Kwh(Asy'ari, Rozaq, \& Putra, 2014).Adapun hasil instalasi akhir ditunjukkan pada Gambar 4. 


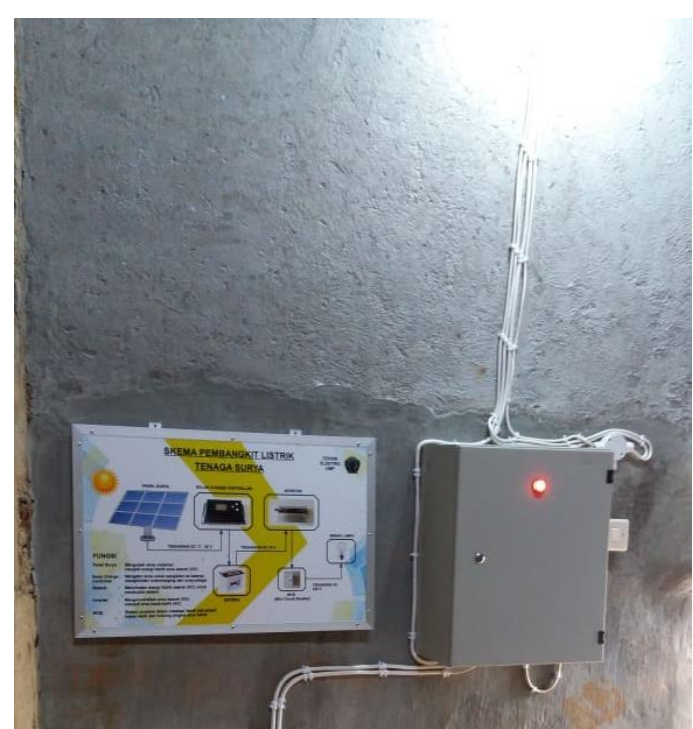

Gambar 4. Instalasi Sistem Pembangkit

Listrik Tenaga Surya

Indikator keberhasilan dari program adalah produk mempunyai tingkat efisiensi sebesar 20\%. Energi yang dihasilkan dariproduk hasil program PPDM ini dapat dimanfaatkan untuk penerangan di area sekitar Kampung Kitiran Rawa Lutung. Selain itu, jumlah pengunjung yang datang ke wahana Desa Wisata Pagak juga semakin bertambah karena adanya objek baru berupa pembangkit listrik tenaga surya.Dengan demikian, pendapatan Desa dapat meningkat seiring dengan peningkatan jumlah pengunjung.

\section{SIMPULAN}

Berdasarkan hasil pelaksanaan Program Pengembangan Desa Mitra (PPDM) di Desa Wisata Pagak, Kecamatan Purwareja Klampok, Kabupaten Banjarnegara dapat disimpulkan bahwa pelaksanaan pengabdian dengan Program Pengembangan Desa Mitra (PPDM) ini berjalan dengan baik. Tingkat antusiasme masyarakat sangat tinggi. Permasalahan yang dihadapi oleh mitra dapat teratasi dengan membangun salah satu ikon yang dapat digunakan sebagai wisata edukasi. Penerapan teknologi kekinian dengan memanfaatkan energy terbarukan sel surya sebagai pembangkit listrik yang dapat digunakan untuk penerangan area sekitar lokasi wisata di Rawa Lutung. Transfer knowledge kepada masyarakat dapat terlaksana dengan baik melalui penyampaian informasi dan ilmu pengetahuan secara langsung.

\section{DAFTAR PUSTAKA}

Abrori, M., Sugiyanto, \& Niyartama, T. F. (2017). Pemanfaatan Solar Cell Sebagai Sumber Energi Alternatif dan Media Pembelajaran Praktikum Siswa Di Pondok Pesantren " Nurul Iman " Sorogenen Timbulharjo , Sewon , Bantul , Yogyakarta Menuju Pondok Mandiri Energi. Jurnal Bakti Saintek, 1(1), 17-26.

Andi, Y., Marlina, T., \& Fahmi, A. (2016). Pelatihan Membuat Laporan Keuangan dengan Microsoft Excel BUMDes Pagelaran. Jurnal Pengabdian Kepada Masyarakat, 1(1), 9-12.

Asy'ari, H., Rozaq, A., \& Putra, F. S. (2014). Pemanfaatan solar cell dengan pln sebagai sumber energi listrik rumah tinggal. Jurnal Emitor, 14(01), 33-39.

Chambers, R. (1994). The Origins and Practice of Participatory Appraisal. World Development, 22(7), 953969.

Kusmuriyanto, Feriady, M., \& Susilowati, N. (2019). Inisiasi Pembentukan Bumdes Bersama untuk Meningkatkan Perekonomian Desa di Kecamatan Jambu Kabupaten Semarang. ABDIMAS - Jurnal Pengabdian Kepada Masyarakat, 23(2), 112-113.

Ramadhan, A. I., Diniardi, E., \& Mukti, S. H. (2016). Analisis Desain Sistem Pembangkit Listrik Tenaga Surya Kapasitas 50 WP. TEKNIK, 37(2), 59-63.

https://doi.org/10.14710/teknik.v37n 
2.9011

Rif'an, M., Pramono, S. H., Shidiq, M., Yuwono, R., Suyono, H., \& Suhartati, F. (2012). Optimasi Pemanfaatan Energi Listrik Tenaga Matahari di Jurusan Teknik Elektro Universitas Brawijaya. Jurnal EECCIS, 6(1), 44-48.

Setianingsih, D., Amdani, Y., \& Utrisno, I. H. (2017). Pemberdayaan Masyarakat dengan Pembentukan kelompok Sadar Wisata untuk Pengembangan Wisata Air Terjun Simpang Kiri di Desa Selamat, Kecamatan Tenggulun, Kabupaten Aceh Tamiang. In Proceeding Seminar Nasional Politeknik Negeri Lhokseumawe (Vol. 1).

Yuliananda, S., Sarya, G., \& Hastijanti, R. R. (2015). Pengaruh perubahan intensitas matahari terhadap daya keluaran panel surya. Jurnal Pengabdian LPPM UNTAG Surabaya, 01(02), 193-202. 